\title{
United Nations (UN) Disaster Risk Reduction Framework: Case Study of the Portuguese Army on UN Challenges in the Context of Sustainable Risk Mitigation
}

\author{
Bruno Martinho ${ }^{1}$ (D) and João Reis ${ }^{1,2, *(D)}$ \\ 1 Department of Military Science, Portuguese Military Academy, Rua Gomes de Fereire 203, \\ 1169-203 Lisbon, Portugal; martinho.bmg@academiamilitar.pt \\ 2 Industrial Engineering and Management, Faculty of Engineering, Lusófona University, \\ 1749-024 Lisbon, Portugal \\ * Correspondence: joao.reis@academiamilitar.pt
}

\section{check for}

updates

Citation: Martinho, B.; Reis, J. United Nations (UN) Disaster Risk

Reduction Framework: Case Study of the Portuguese Army on UN Challenges in the Context of Sustainable Risk Mitigation. Sustainability 2022, 14, 1834. https:// doi.org/10.3390/su14031834

Academic Editors: Gitana Dudzevičiūtè and Ieva Meidutè-Kavaliauskienè

Received: 15 January 2022 Accepted: 2 February 2022 Published: 5 February 2022

Publisher's Note: MDPI stays neutral with regard to jurisdictional claims in published maps and institutional affiliations.

Copyright: (c) 2022 by the authors. Licensee MDPI, Basel, Switzerland. This article is an open access article distributed under the terms and conditions of the Creative Commons Attribution (CC BY) license (https:// creativecommons.org/licenses/by/ $4.0 /)$.

\begin{abstract}
The United Nations (UN) in the context of disaster risk reduction has been sensitizing governments and all citizens to the need to develop mechanisms that contribute to preventing risks and reducing vulnerabilities regarding serious accidents or disasters. The search for an adequate response to the different types of accidents is a social demand; leading civil protection authorities, together with other national entities, namely the Armed Forces, to create diverse response mechanisms. This research intends to call the reader's attention and awareness to disaster risk reduction, characterizing the UN policy, and evaluating the Portuguese Army's capacity for organizational change. This article follows a case study research strategy, considering a deductive reasoning structure and a qualitative methodological orientation. The evolution of the UN's growing concern with disaster risk reduction over time will be studied, and the way in which the Portuguese military has adapted to the new challenges promoted by the UN will be discussed.
\end{abstract}

Keywords: organizational change; leadership; United Nations; disaster risk reduction; civil protection; Portuguese Army; emergency military support unit

\section{Introduction}

Annually, the UN celebrates the International Day for Disaster Reduction. The celebration is an important milestone in disaster reduction and has been instituted since 1989 . The UN aims to sensitize governments, organizations, and citizens around the world to the need to develop collaborative actions that prevent risks and reduce vulnerabilities. At the same time, it increases communities' resilience and capacity to anticipate and respond to the occurrence of serious accidents or catastrophes. Disaster risk reduction is a complex issue that, taken preventively, can save many human lives. This issue should not be solved independently by a nation or institution, as it is necessary to bring together collective efforts and combined knowledge from all sectors of society, whether public or private or from other active members of civil society [1]. Recently, the UN Secretary General António Guterres stated that "the risk of disasters is not the exclusive responsibility of local and national authorities" [2]. The idea is to create a political commitment at the highest level to meet the Sustainable Development Goals (SDG) [3,4], which include the Sendai Framework for Disaster Risk Reduction 2015-2030 [5]. In Portugal, the Sendai Framework is included in the National Preventive Civil Protection Strategy 2030 [6]. The search for an adequate and effective response to different types of disasters is see by the UN as a social call; one that leads civil protection authorities, together with other national entities, namely the Army, to make intensive efforts to keep people safe.

This article analyzes the receptivity of the Portuguese Army in developing actions that contribute to disaster risk reduction. These actions required the Portuguese Army to 
pursue organizational change. To study the risk reduction phenomenon and develop more awareness about this issue, we decided to conduct some scientific research in this regard. The objective was to uncover how organizations are managing risk reduction and the way they are changing in order to do so. Therefore, we used a case study [7] that analyzes the creation of the Emergency Military Support Regiment (EMSR). The option of using this case study research is due to the rich data that the Armed Forces can provide in describing the phenomenon. By conducting this research, we are convinced that readers will have a better understanding of real life [8]. To obtain this understanding, the analysis and discussion of the case study was based on different sources of data collection, which included semistructured interviews, official documents, and direct observation. The respondents were selected because they are officers who have performed risk and disaster reduction roles within the Portuguese Army.

This research was spatially, temporally, and conceptually delimited. In that regard, this study will be spatially delimited by studying risk and disaster reduction in mainland Portugal (excluding the Portuguese islands). It is also limited in time because it exclusively considers the timeframe 2014-2021, the dates within which the organizational transition from the predecessor unit to the EMSR began. Regarding the conceptual content, this research focused exclusively on the organizational change of the EMSR in light of the theory of John Kotter [9]. This research article has a general objective, which is to describe how the risk and disaster reduction phenomenon takes place within the scope of organizational change in the Portuguese Army, according to Kotter's theory. This resulted in the following research question: How did the Portuguese Army reduce risks and disasters within the scope of the UN's disaster risk reduction policy, using Kotter's theory of organizational change?

The main results reveal that, according to John Kotter's theory [9], the Portuguese Army managed to overcome some challenges in terms of resistance to change. That is, the Portuguese Army completed seven of eight stages. The gap is due to the empowerment of others to act in line with the institutional vision, as in the scope of our analysis we found that this step is difficult to achieve due to the hierarchical nature of the military organization.

This article is organized into five parts: introduction, conceptual framework, research methodology, results and discussion, and conclusions. In the theoretical framework, we analyze and characterize the UN's policy for disaster risk reduction. Then, we analyze the methodological framework, relating to the type of reasoning, research strategy and research design. In this section, we also characterize the participants and research instruments, explaining the reasons for adopting the procedures used for data collection, as well as the data analysis techniques. Following this, we present the results, in particular, concerning the creation and sustainability of the EMSR. Finally, we present our conclusions, taking into account how the research would not be possible to conduct without the relevant contribution of the existing literature.

\section{Conceptual Framework}

\subsection{Risk, Vulnerability and Resilience}

The concept of risk has received scholarly attention from several angles in the social, technical, and natural sciences [10]. However, there is no consensual definition of risk, or its vulnerability and resilience to a system [11-13]. In that regard, notable researchers, such as Haimes [11], have been explaining that the most efficient approach can be taken from a philosophical or methodological point of view, as conceptualizing risk is difficult due to its multidimensionality and nuance. Defining the concept requires that we understand that risk to a system is inherently and fundamentally a function of the initiating event, the states of the system and its environment, and the time period. In light of the above, Haimes [11] (p. 1647) by defining risk posits that: (a) the performance capabilities of a system are a function of its state vector; (b) a system's vulnerability and resilience vectors are each a function of the input (e.g., initiating event), its time of occurrence, and the states of the system; (c) the consequences are a function of the specificity and time of the event, the vector 
of the states, the vulnerability, and the resilience of the system; (d) the states of a system are time-dependent and commonly fraught with variability uncertainties and knowledge uncertainties; and (e) risk is a measure of the probability and severity of consequences. The important thing to retain is that, within the risk framework, the consequences for each risk scenario must be evaluated depending on the initiating event (i.e., the threat), the vulnerability and resilience of the system, and the timing of the event. Enhancing community and system resilience can lead to major savings through risk reduction and rapid recovery [14]. It is in this regard that risk reduction and rapid recovery approaches should seek to understand how communities learn from their dangerous experiences and transform these lessons into beliefs, relationships, and capacities that build future adaptive capacity $[15,16]$.

\subsection{Realism, Liberalism and Constructivism in the Search of Security}

According to security studies and military science schools of thought, after the World Wars, different paradigms emerged that aimed to identify and explain the causes of war and develop strategies to achieve this goal. In general, the best-known theories are realism, liberalism, and constructivism.

Realism, in a simplified version, is a school of thought that explains international relations in terms of power [17-19]. One of the main assumptions of this theory is that the key actor in the international system is the State [20]. Although other actors can be considered, such as transnational corporations, their role is limited [21]. Therefore, the State, which has a series of national interests, is defined in terms of power [19]. Liberalism, in turn, turns its attention to how war can be eradicated [21], and international actors can identify peaceful methods of resolving disputes [22]. Finally, constructivists present a new approach in which they believe the prevailing theories are wrong [23]. Hence the argument that the State is not a given, but a social construction, which may have different interests depending on the identities at a given moment [21].

Our analysis is that the three paradigms are concerned with identifying the causes of conflicts and developing strategies to ensure community security. Although these paradigms are usually analyzed from an international relations perspective, they may be relevant to understanding State intervention in risk reduction. Of particular note is the solution proposed by constructivists, who emphasize identity as an essential element in the formation of security communities. That is, identifying how community members and their interactions leads to the creation of a collective identity that increases the chances of making the community more resilient. In other words, identifying how community members and their interactions lead to the creation of a collective identity increases the chances of making society more resilient. Although security is not just the responsibility of the State, it has an active and very relevant role in the security of the community. It was in this context that the Portuguese State, through the Army, together with the civilian community, responded to the UN call in the context of disaster risk reduction.

\subsection{United Nations and Disaster Risk Reduction}

In recent decades, the scientific community has witnessed an increasing occurrence of disasters that have caused serious damage to humanity. The challenge involved in the fight against natural disasters has led the international community to admit that humanity will face a global threat never before felt $[24,25]$. Numerous facts point to human negligence in relation to the environment as the main cause of these occurrences, which is progressively leading to an acceleration of climate change. We can analyze, according to the UN report on disaster risk increase in 2020 (Figures 1 and 2), that "the first 20 years of the 21st century was marked by an impressive increase in climate disasters; in that period, 7348 disasters occurred around the world; approximately 1.23 million people died, about 60,000 a year. In addition, more than 4 billion people were affected" [26]. 
Total disaster events by type: 1980-1999 vs. 2000-2019

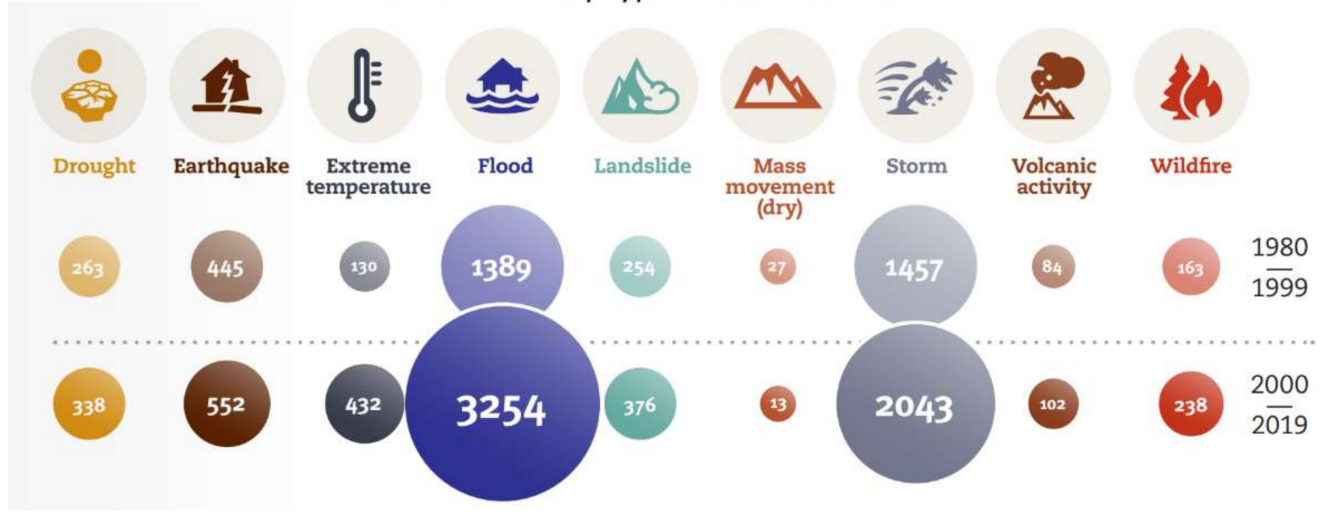

Figure 1. Natural disasters recorded between 1980-1999 and 2000-2019 [26].

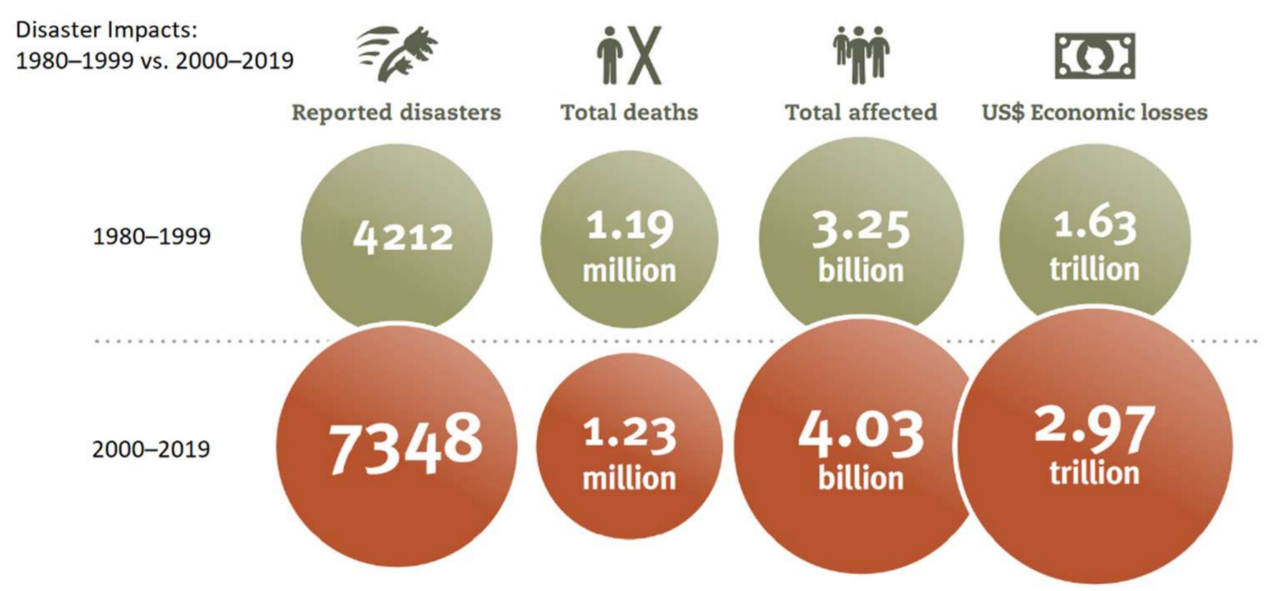

Figure 2. Impact of natural disasters recorded between 1980-1999 and 2000-2019 [26].

The studies carried out so far are beginning to shed light on the establishment of a cause and effect relationship between climate change and the frequency and intensity of extreme events $[27,28]$. On top of that, there is an increasingly developed consensus on the intuitive relationship between climate change adaptation and disaster risk reduction [29].

The growing trend of these phenomena led the international community to make a decision, which led the UN General Assembly, in 1989. This General Assembly approved the Resolution 44/236, which designated the 1990s as the International Decade for Natural Disaster Reduction [30]. Resolution 44/236 highlighted some existing technical and scientific resources to face the global threat and proposed that international action take place. In 1994, the 1st World Conference on the Prevention of Natural Disasters took place [31]. In that conference, the Yokohama Action Plan was presented for the first time, which moved to the creation of a disaster reduction policy with community social orientations. To organize an international strategy for disaster reduction, the $\mathrm{UN}$ created a permanent secretariat in Geneva [32].

In 1999, the UN implemented the International Strategy for Disaster Risk Reduction (UNISDR) [33], with a focus on increasing communities' resilience in the face of current disasters. The UN defines resilience as "the ability of a system, community or society exposed to hazards to resist, absorb, accommodate, adapt to, transform and recover from the effects of a hazard in a timely and efficient manner, including through the preservation and restoration of its essential basic structures and functions through risk management." [34]. The UNISDR is a global network structure, consisting of a system of national platforms that seek to strengthen, at the national level, a set of political, legal, social, and technical 
arrangements. The UNISDR pursues the reduction of vulnerabilities in the face of the global threat of catastrophe. One of the focuses of the UNISDR is to actively monitor progress in implementing the Hyogo and Sendai Declarations [1]. The national platform for disaster risk reduction is a generic term for national mechanisms. It aims to coordinate and guide disaster risk reduction policies that are multisectoral and interdisciplinary in nature. They rely on the participation of civil society, both public and private, involving all interested entities in a country. Disaster risk reduction requires the knowledge, skills, and contributions of a wide range of sectors and organizations, including UN agencies present at the national level. Most areas are directly or indirectly affected by disasters, and many have specific responsibilities that interfere with disaster risks. Thus, national platforms provide the means to improve national action to reduce disaster risks and represent the national mechanism of the UNISDR [35].

In 2005, at the 2nd World Conference on Disaster Reduction, in Japan, the Hyogo Action Framework 2005-2015 was adopted [36]. This conference defined five global priority actions and the main tasks to be adopted by countries, organizations and other entities involved in the risk management of disasters according to the following contexts [37]:

- Ensure that disaster risk reduction is a national and local priority, with a strong institutional foundation for its implementation;

- Identify, assess and monitor disaster risks and increase early warning;

- Use knowledge, innovation and education to build a culture of safety and resilience;

- $\quad$ Reduce key risk factors;

- Strengthen disaster preparedness for an effective response at all levels of risk management.

In March 2015, the 3rd World Conference on Disaster Risk Reduction took place (Sendai 2015-2030 Framework) [38], succeeding the Hyogo Framework for Action 20052015. The Sendai Framework resolution implemented some changes to the existing Disaster Risk Reduction 2015-2030 framework, with a much broader scope than that decided at the previous conference. Specifically, there was a shift from a disaster management concept to a disaster risk management concept, with a more preventive perspective. The main objective of this new vision for the years 2015 to 2030 is to prevent new risks, as well as reduce the risks of existing disasters, through the implementation of integrated and inclusive measures at the economic, structural, legal, social, health, cultural, educational, environmental, technological, political, and institutional levels [38].

According to the UNDRR 2015 (United Nations Office for Disaster Risk Reduction) publication, the Sendai Framework 2015-2030, regarding the scope of resilience and risk reduction, is based on four priorities [5]:

- Deepening knowledge about disaster risk;

- Strengthening the disaster risk management component;

- Investing in the disaster risk reduction component for better resilience;

- Strengthening the preparedness component for an effective response.

The international structure evolved towards a progressive shift, moving from consequence management to risk management; that is, a transition from response to prevention [6]. In Portugal, the Sendai Framework was partially copied to the National Preventive Civil Protection Strategy 2030 (NPCP 2030). The NPCP 2030 was defined by the Portuguese Council of Ministers Resolution n. 112/2021 [39]. The NPCP strategy is part of an international context framed by three relevant global risk management strategies, all adopted in 2015: (1) Sendai Disaster Risk Reduction Framework (main reference); (2) the Paris Agreement on Adaptation to Climate Change [40]; and (3) the Sustainable Development Goals for 2030 [41].

\subsection{Risk Reduction in the Portuguese Republic}

In accordance with the Portuguese law n. 27/2006 [42], Civil Protection is responsible for conducting activities carried out by the State, the autonomous regions, and the local authorities. These activities can be conducted by citizens and by all public and private enti- 
ties with the aim of preventing any collective risks due to situations of serious accident or catastrophe. Thus, Civil Protection aims to mitigate the effects of accidents or catastrophes; protecting and helping people and property in danger [42].

In turn, the National Emergency and Civil Protection Authority (ANEPC), in the matter of emergency and civil protection, is the national authority-with the main objective of planning, coordinating, and executing emergency and civil protection policies [43]; namely, in the prevention and response to accidents and major disasters. This authority coordinates with the Civil Protection Agents and ensures the planning and coordination of national needs in the area of civil emergency planning.

In order to comply with UN recommendations, Portugal put together, in 2010, the National Platform for Disaster Risk Reduction (PNRRC) [44], which is operated by the ANEPC. The objective of the PNRRC is to implement an activity plan that includes actions in the domains of the Hyogo Framework for Action and the Sendai Framework [44].

The ANEPC uses the National Civil Protection Emergency Plan (PNEPC) to respond to civil protection operations in the event of serious accidents or catastrophes in mainland Portugal [45]. The PNEPC consists of a platform prepared to respond in an organized way to situations of serious accident or catastrophe, defining the structure responsible for Coordination, Direction, Command and Control. This plan also shows how coordination is carried out between the organizations that are part of the Integrated System of Protection and Relief Operations (SIOPS) and other public or private entities involved in the operations [46]. To provide an adequate response at the operational level, ANPEC has a set of Civil Protection Agents, which are organized within the scope of the SIOPS. Thus, the SIOPS is the "set of structures, rules and procedures of a permanent nature that ensure that all Civil Protection Agents act, at the operational level, articulated under a single command, without prejudice to the respective hierarchical and functional dependence" [46].

The Armed Forces (FFAA) as Civil Protection Agents are also part of the SIOPS and provide resources and skills in the Emergency Military Support (EMS) on demand. The EMS is foreseen in the FFAA mission in the "scope of public interest missions, cooperating with the molds and security services and collaborating in tasks related to the satisfaction of basic needs and the improvement of the quality of life of the population" [47].

According to the Portuguese Resolution of the Council of Ministers n. 19/2013 [48], it is necessary to strengthen the Civil Protection System, intensifying the use of operational synergies between the entities responsible for the areas of internal security, justice and national defense and the administration. This reinforcement makes it possible to improve the efficiency and effectiveness of the system through the development of methodologies, programs and technical-scientific studies on various hazards, threats, and risks. In that regard, it is essential to create Military Emergency Care Units (i.e., EMSRs) and to deepen the connection and response capacity of the Armed Forces with the network of entities responsible for disaster and calamity situations. As a starting point, the Portuguese Military Strategic Concept (MSC) [49] decided, as a guiding principle, to build a system of forces dedicated to the generation of civil-military synergies. The objective is to develop military capabilities and integrated civilian capabilities. In that regard, the MSC reinforces the fact that the creation of a Military Emergency Unit and the valorization of the principle of "dual use" is of paramount importance [49].

This research analyzed a single Army Unit, as the unit of analysis (i.e., a Military Emergency Unit) is approximately 5 years old, as dated from its inception. The opportunity was taken to allow a holistic understanding of the creation of military capabilities integrated with civilian capabilities to the present day. However, the reader may wonder why the National Republican Guard (GNR) was not studied. Why an Army military unit? What happens is that the Emergency Protection and Relief Unit of the Portuguese National Guard was created in 2006 [50], so it would be more difficult to collect information (e.g., interviews) ranging from its creation to the present day. In addition, some of the military personnel responsible for its creation are no longer in active service. Hence the relevance of this article is due to the collection, analysis and reporting of a timely case. On the other hand, a 
mixed study is also difficult to conduct since there are still not enough synergies between the Military Emergency Unit of the Army and the Republican National Guard that justify research of this depth. In our understanding, the synergies are not yet mature enough because, although both units are of a military nature, the Military Emergency Unit of the Army belongs to the Portuguese Ministry of National Defense, while the GNR belongs to the Ministry of Internal Affairs. However, it is likely that, over time, there will begin to be greater cooperation between the Army and GNR forces, which could become a good research opportunity.

According to dispatch n. 44 of the Chief of Staff of the Portuguese Army [51], the EMS is understood as the participation of the Army in the response to complex emergencies; namely, accidents or serious calamities, therefore, providing support to affected populations and assisting from a logistical point of view, emergency communications, engineering, and health support [52]. As set out in the MSC, the EMS is based on the principle of "dual use". According to Palma 2011 [53], the dual based principle is founded on the use of FFAA resources in the military and non-military public services, enhancing synergies and managing resources within the scope of logistical support. According to the capabilities that are expected from the EMS, the Army will be able to count on all forces and/or means that can employ their actions in this scope. Exclusively, those that make up its operational and fixed components, e.g., the forces designed and built to strictly fulfill military missions [54].

In 2016, following the Portuguese Army Staff (n. 114/CEME/16) publication, the general instructions for the creation and entry into operation of the EMSR were published, having begun operations as of 1 November 2016. According to Barroso [55], the EMSR has unique capabilities when responding to crises and, in particular, because it has military units spread across the various geographic regions of the country, being managed by the Emergency Military Support Operations Center (COAME). The EMSR is a Fixed Component Unit of the Army's Land Forces System that is responsible for preparing the UAME (Emergency Military Support Unit), which reports hierarchically to the Portuguese Army's Land Forces Command (CFT). The UAME's mission is to support the development and well-being of the population; namely, in response to serious accidents or disasters. The UAME seeks to build the maximum synergies within the elements of the operational component of the EMSR, through its "dual use" concept.

In Figure 3, it is possible to identify the UAME's organic framework. It is worth noticing that it complies with a Command Group, General Staff, Emergency Military Support Operations Center, Emergency Intervention Group and Dual Use Detachment. The Emergency Intervention Group is the structure, with resources exclusively dedicated to the EMS. Subsequently, the UAME has a flexible structure that can be adapted to the specificity of each mission - which is the same to say that the Dual Use Detachment has competences in the field of fighting rural fires, search and rescue, and surveillance, among others. In short, the UAME's structure is essentially based on two axes, the 1st axis consisting of a minimum permanent service support structure, and the 2 nd axis is reinforced by additional means, depending on the type of mission.

Overall, the UAME can fulfill the following missions and tasks:

- Ensure the Command and Control (C2) to the EMS;

- Ensuring synchronization and synergy in the use of the different Intervention Modules of the Army's Integrated EMS System that incorporate its nine intervention capabilities, shown in Figure 3;

- In coordination with the Portuguese Army's Land Forces Command (CFT), the UAME studies and plans the use of Army assets in the field of civil protection;

- Plan the different scenarios for the use of the UAME's capacities.

In addition, the Portuguese Army Emergency Military Support Plan (PAMEEX) aims to establish the rules under which the Military Support for Civil Emergencies act [56]. The purpose of PAMEEX is to establish the form of collaboration with the Army regarding the prevention and response to complex emergencies. In that regard, PAMEXX addresses the UAME's EMS capabilities, which were the result of the 2014 Forces System implementation, 
and which are organized in nine areas of activity (Figure 4). These nine areas of intervention are focused on several intervention responses to crises, such as extreme events caused by terrorist attacks, forest fires, floods, earthquakes, and volcanic eruptions, among other crises. Although not exclusive, the UAME's area of activity is focused on the prevention and action against events originating from natural causes. The selection of these events is in accordance with the reports presented by the UN (see Figures 1 and 2).

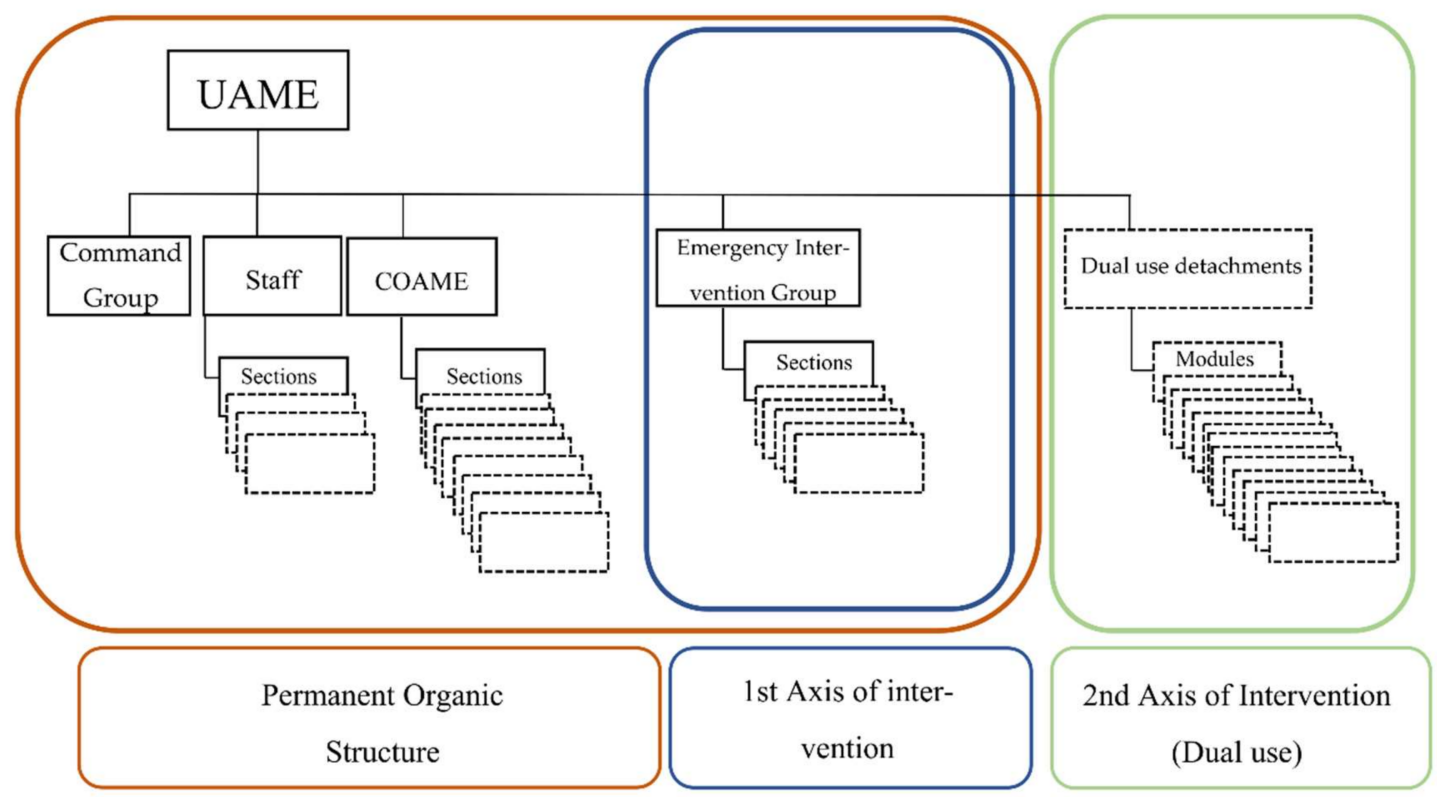

Figure 3. UAME's structure.

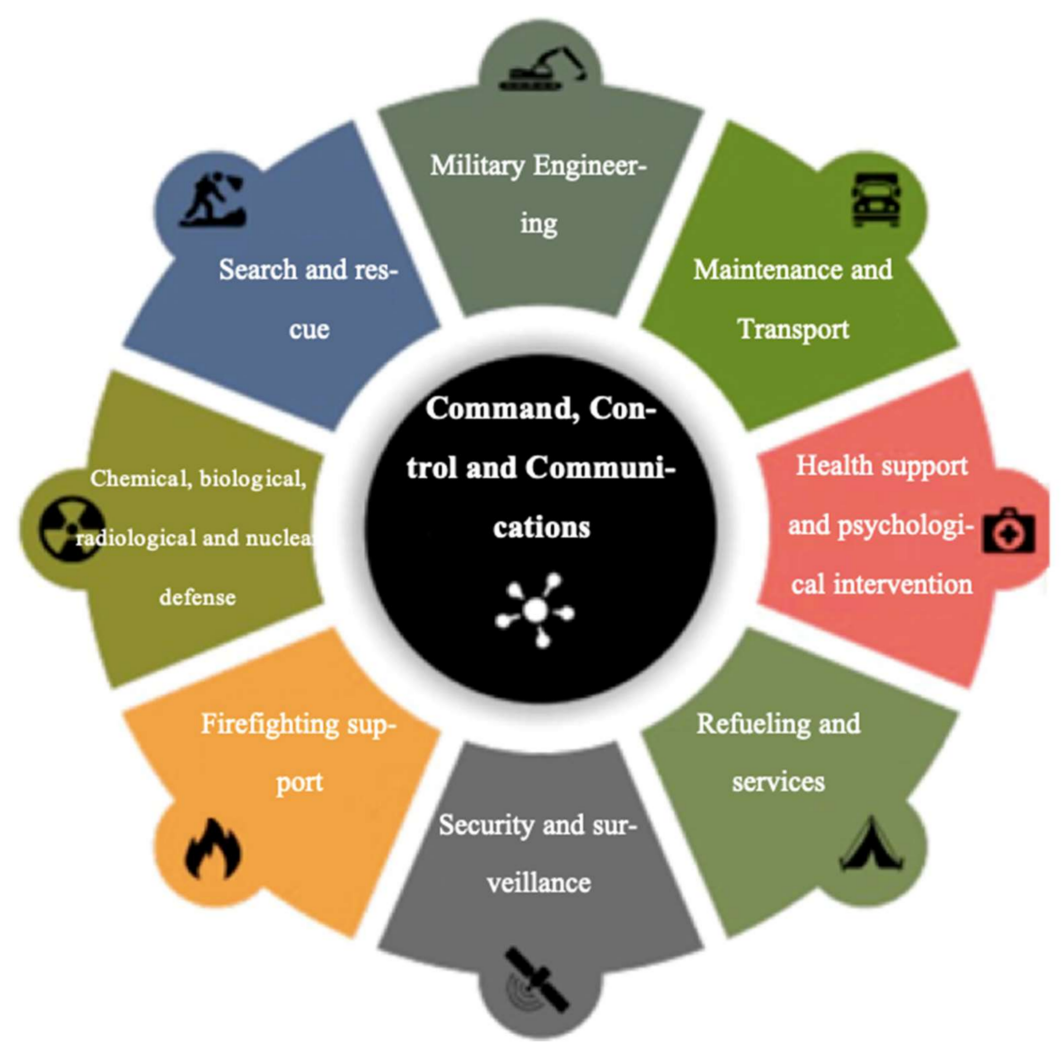

Figure 4. The UAME's EMS Capabilities. 


\subsection{Organizational Change}

Change is a complex transformational process with a high probability of failure. The concept of change can be defined as any transformation of a structural, cultural, technological, human or other nature, capable of impacting parts or the whole of the organization and which requires a well-planned line of effort [57].

No matter how well prepared an organization is, it is likely to face resistance to change. Resistance can be of an individual or organizational origin. So, if on the one hand resistance can be positive, since it provides predictability and stability to the behavior of organizations; on the other hand, it can be a source of functional conflict and can decrease adaptability and, consequently, organizational progress. Thus, it is necessary to mitigate the mechanisms of resistance through communication [58], participation, and the sharing of a vision by all members of the organization [59].

Change begins with a critical idea and a desire for modification, which can be based on frustration or dissatisfaction and must be oriented towards attractive and achievable goals. Thus, change is a process that must be done for the improvement of an organization, but it needs leaders to take over the process and has a high chance of failure [60].

Organizational Change is an essential element for the permanent updating of all organizations. Changing mindsets and creating new ideas is a big challenge. In this regard, John Kotter [9] brought a significant advance to overcome the failure of change by developing a theory, dividing Organizational Change into eight essential steps:

Step 1-Establishing a sense of urgency-Involve the people who will participate in the change. It is necessary that all employees understand the reasons for the change and the importance of acting immediately, so that motivation can be awakened in each one of them.

Step 2-Forming a powerful guiding coalition-Identification of employees and managers who can serve as agents of change. These people can be chosen not only for the position they hold, but also for their status and experience in the subject. In practical terms, they will be able to influence the people in their circle during the change process and help eliminate problems before they even arise.

Step 3-Creating a vision-It is necessary to develop a vision that aligns with the main values related to change, in a highly concise and objective way, allowing everyone to quickly understand what will need to be done on a day-to-day basis to adapt to the new situation.

Step 4 - Communicating the vision-Communication must be comprehensive and clear, encouraging employees to implement the "vision of change" and to have a growth perspective.

Step 5-Empowering others to act on the vision-In this phase, a decentralization of powers is proposed, i.e., there is a greater participation of the workers in the company's activities, being granted decision-making autonomy.

Step 6-Planning for and creating short-term wins-Create short-term intermediate goals so you do not lose momentum, as true transformation takes time. It is important to have tight deadlines to meet and celebrate each milestone achieved.

Step 7-Consolidating improvements and producing still more change-Although short-term gains are attractive at first, real changes take some time to be fully absorbed. At this stage, it is necessary to consolidate improvements and promote more changes.

Step 8-Institutionalizing new approaches-In this last stage, the institutionalization of the new approaches is carried out. It is necessary to make change a common part of the organization's culture.

\section{Materials and Methods}

This article follows a case study. It has a qualitative orientation and follows a deductive approach. The option for choosing a case study strategy is justified by the need to evaluate the response of the Portuguese Army to the organizational change within the scope of the UN. To do so, we have defined three methodological phases: the exploratory phase, the analytical phase, and the conclusive phase. 
The exploratory phase aimed to search for scientific articles, legislation, and other supporting documents [61]. The analytical phase was based on the collection and interpretation of several data sources, such as semi-structured interviews, direct observation, and official documentation. Within the scope of the interviews and, similar to other research [62,63], we selected highly acknowledgeable respondents who were responsible for the creation of the UAME and the EMSR. Therefore, the respondents were selected through convenience sampling [64], based on accessibility and knowledge in the area. They were: (1) its first director; (2) an officer who led the organizational transition from the UAME to the EMSR structure; (3) a third officer who was the head of military operations and who later assumed relevant roles in the EMSR's Emergency Military Support Operations Center; and lastly, (4) a fourth officer who followed the entire transformational process from the creation of the EMSR, therefore, from 2014 to the present (Table 1). Although the survey has few interviews, the respondents were able to describe the phenomenon from different perspectives, regarding the creation of the UAME and its transformation into the EMSR. To obtain greater research accuracy, we also analyzed official documents produced by the Portuguese Army, the Portuguese Government, and the National Authority for Emergency and Civil Protection, although they were not limited to these. A sample of those documents can be found in Table 1. However, in order not to have an excessively extensive table, we decided to include only the most relevant ones. Overall, 5720 pages of official documentation were analyzed. This data collection source was a key part of the investigation, having also been combined with other open sources (e.g., Internet) for corroboration and triangulation purposes. Direct observation was another powerful tool that has provided a first-hand account of the phenomenon. As part of this data collection technique, a research diary was used [65], which allowed us to collect additional information in the greatest possible detail. The information was recorded in field notes, collected through informal conversations and from discussion in seminars. The record included comments, direct quotes, and respondents' behaviors [66]. A common criticism directed at qualitative research is that it does not adhere to cannons of validity [64]. To reduce criticism, we added measures to allow for validity, i.e., instruments to measure what is intended to be measured, and reliability, i.e., the findings are replicable or repeatable. Regarding reliability, the first researcher made use of a protocol that allows replication. As for validity, we used multiple sources of data collection as a form of triangulation, to avoid exclusive dependence on a single data collection method. This technique helps neutralize any bias inherent in a given data source [64]. In addition, the recording of interviews allowed the researchers to send transcripts to the respondents to clarify if what they meant was in fact what the researcher had perceived and interpreted.

The analytical phase ended with the content analysis [67]. This technique allowed us, after reading all of the content (i.e., transcripts, field notes and official documentation), to identify the most relevant phrases and ideas. During the coding process, we classified the categories and subcategories [68]; that is, we had to find patterns in the codes to identify the most relevant ideas, generating a map that allowed us to have an overview of the data [69].

Finally, the conclusion phase was where the focus was to evaluate, interpret and debate the results obtained; seeking to identify gaps and contributions in the organizational change process of the Portuguese Army. Additionally, we presented the conclusions and recommendations to stimulate higher discussion on the themes of disaster risk reduction. 
Table 1. Data collection sources.

\begin{tabular}{|c|c|c|}
\hline Rank & Position & Interview Date \\
\hline Captain & Company Commander & 25 November 2021 \\
\hline Major & $\begin{array}{c}\text { Head of the operations of the } \\
\text { EMSR }\end{array}$ & 2 December 2021 \\
\hline Colonel & $\begin{array}{l}\text { Director of the EMSR } \\
\quad(2016-2019)\end{array}$ & 3 December 2021 \\
\hline Colonel & $\begin{array}{l}\text { Director of the EMSR } \\
\quad(2013-2016)\end{array}$ & 29 December 2021 \\
\hline Rank & Position & Direct Observation Date \\
\hline Captain & $\begin{array}{l}\text { Liaison Officer with the } \\
\text { ANEPC }\end{array}$ & 12 November 2021 \\
\hline Captain & $\begin{array}{c}\text { Representative of the Armed } \\
\text { Forces }\end{array}$ & 7 December 2021 \\
\hline Seminars & UAME Role and actions & 3 December 2021 \\
\hline Seminars & UAME Role and actions & 15 December 2021 \\
\hline Coronel & $\begin{array}{l}\text { Director of the EMSR } \\
\quad(2019-2021)\end{array}$ & 28 January 2022 \\
\hline Type & Title & $\begin{array}{c}\text { Official } \\
\text { Documents(Publication } \\
\text { Date) }\end{array}$ \\
\hline SIOPS 72/2013 & $\begin{array}{l}\text { Integrated System of } \\
\text { Protection and Relief } \\
\text { Operations }\end{array}$ & 30 November 2011 \\
\hline 19/2013 DRE & $\begin{array}{l}\text { Strategic Concept of National } \\
\text { Defense }\end{array}$ & 5 April 2013 \\
\hline 44/CEME/2017 & $\begin{array}{c}\text { Emergency Military Support } \\
\text { Concept }\end{array}$ & 14 March 2017 \\
\hline PAMEEX & $\begin{array}{c}\text { Military Emergency Support } \\
\text { Plan }\end{array}$ & 26 June 2018 \\
\hline 45/2019 DRE & $\begin{array}{l}\text { National Emergency and Civil } \\
\text { Protection Authority }\end{array}$ & 1 April 2019 \\
\hline PNEPC & $\begin{array}{c}\text { National Civil Protection } \\
\text { Emergency Plan }\end{array}$ & 24 March 2020 \\
\hline
\end{tabular}

\section{Results and Discussion}

Organizational Change: The Case Study of the Creation of the UAME in the Light of John Kotter's Theory

Since 2001, Portugal has designated the National Emergency and Civil Protection Authority (ANEPC) as the responsible organization (at national level) for the purposes of the international strategy for disaster risk reduction. To comply with UN recommendations, Portugal had also created the National Platform for Disaster Risk Reduction (PNRRC). In this context, the PNRRC aims to implement an activity plan containing actions in the areas of the Hyogo Action Framework and the Sendai Framework [38].

With regard to the performance of the Armed Forces in Civil Protection missions, their mission is framed by Portuguese legislation. For example, the Strategic Military Concept [49] gives the Army the ability to act within the Emergency Support Concept (defined in the Strategic Concept of National Defense under the Resolution of the Council of Ministers n. 19/2013) [48]. The strategic concept of national defense determines the creation of a Military Unit that operates in the scope of disaster risk reduction. This Military Unit acts in the framework of "dual use", which allows the deepening of the FFAA's response capacity in disaster and calamity situations. This Unit was established in 2016, with the creation of the Emergency Military Support Unit. To follow, in this subchapter, we present the case study regarding the creation of the Emergency Military Support Unit in the light of John Kotter's theory [9]. Thus, this research has the objective of evaluating the Organizational Change capacity of the Portuguese Army. 
Step 1-Establishing a sense of urgency-To create the UAME, it was necessary to identify from scratch a regiment with a well-defined organizational and hierarchical structure to assign it a new identity. The first steps were guided by the UAME's Implementation Plan to guide the transition from an existing military structure. Thus, the regiment Escola Prática de Cavalaria was the ground zero for the creation of an EMSR. With the creation of a feeling of belonging to the Unit, objectives were developed, such as the creation of a division and a heraldry with the coat of arms of the unit. The development of the mission sentiment and the elimination of individual and organizational resistance were also valued. The military involved felt that the creation of the UAME was indeed a necessity for civil society and a priority for the Portuguese Army.

Step 2-Forming a powerful guiding coalition-Although hierarchically dependent on the upper echelon, the UAME has a well-defined command unit. The command unit is headed directly by the UAME Commander, who also relies on the Staff and the COAME to advise him (Figure 3).

Step 3-Creating a vision-According to the respondents and the Portuguese Ministry of National Defense, the Armed Forces defined the Concept of Military Support to Civil Emergencies, which became effective for the FFAA and has the following purpose (among others):

- To identify the central idea that characterizes a new joint approach by the FFAA;

- To identify common foundations and operating principles;

- To lay the foundations for the development of a joint doctrine;

- To identify the capabilities and actions needed, at different levels, to validate and implement the present concept.

As such, the UAME defined the following development vectors: doctrine, organization, personnel, training, material, leadership, infrastructure, and interoperability. In this regard, the UAME has a mission to collaborate in the context of supporting the development and well-being of the population; namely, in response to accidents and disasters. It also developed a vision of action and employment based on two axes of intervention (Figure 3). The first axis aimed to expand the capabilities dedicated exclusively to Emergency Military Support. The second axis contemplates the valorization of the "dual use" equipment of the different units of the system of military forces assigned to the intervention modules, and which serve each valence of the Emergency Module (Figure 4).

Step 4-Communicating the vision-The vision of change was obtained via seminars on the topic of Emergency Military Support, where the possibility of communicating inside and outside of the institution arose. These seminars aimed to promote introspection on the new challenges in this area; namely, in terms of the Army's employment capabilities, as well as on the future organizational model, still in the implementation phase.

There was also a strong focus on training, as several training courses were given in the context of training soldiers, so that the next soldiers to join the EMS missions already had adequate training. In this context, the creation of the CAME (Course of Emergency Military Support) for all graduated military also arises.

Step 5-Empower others to act on the vision-The military institution requires a structured hierarchy, where events on major decisions are determined by the Commander and advised by his General Staff and the COAME. Therefore, as it is a military organization, the UAME loses some freedom of action when compared to other civil organizations. With regard to individual commitment within the military at the UAME, we note that there are no problems related to professional expectations (promotions, public recognition of opportunities, etc.). That is, the military who work at the UAME felt fully committed to their duties since they believe that their activity brings practical and tangible contributions to society. As the UAME belongs to the Elements of the Operational Component of the Forces System (ECOSF), military commendations have a greater impact on their career; however, those military feel that this is not important when compared with the feedback received from the local population. An example that highlights the previous arguments concerns the task of evacuating people during the occurrence of major fires in Portugal in 
$2017[70,71]$, and the respective face-to-face thanks of the population within the scope of these operations. Therefore, the military consider social recognition more rewarding than one that allows for career progression.

Step 6-Planning for and creating short-term wins-According to the data, the shortterm achievements were reached with the recognition of the civil institutions and the respective requests for support. The relevant challenge to the UAME was in 2017, when they supported the civil instructions to fight the great fires that devastated Portugal [70,72]. The wildfires resulted in a record 500,000 hectares burned, with forest devastation ranging from the north to the center of the country [71] and more than 120 lives lost [70]. That said, the UAME, which was a newly created unit, had to use its full capacity. That is, the requested support was so demanding that the UAME had to activate all of its 1st and 2nd vector capabilities. It was, therefore, the first time that the UAME had to resort to certain intervention modules (2nd vector), such as psychological support, food delivery, body search and recovery, transport service for the elderly, and so on. After this activity, the UAME's military felt more prepared to respond to future requests from civilian authorities, as some previous unused means were put to the test. The UAME works mainly through requests for support and acts in the context of emergency situations; these small achievements helped to create a sense of accomplishment and success within its personnel.

Step 7-Consolidating improvements and producing still more change-A good example of this stage is the annual FÉNIX exercise, created in 2018. This exercise aimed to test the level of response of the Integrated Protection and Relief Operations System in an exceptional emergency situation. During the exercise, the UAME had the opportunity to test and consolidate its capabilities and continue the development of its TTPs (Tactical Techniques and Procedures). The UAME's commitment is detailed in the activity reports, providing a good assessment of its performance, and producing metrics that document newly proposed changes for the future. An example of this application is the recent change in the structure of the UAME (Figure 3), which incorporates a new module-the Emergency Intervention Group. This innovation comes from the analysis of reports and metrics raised mainly in the experience of the 2017 fires [70], with the objective of structuring the command, control, and communications of the UAME.

Step 8-Institutionalization of new approaches-At this stage, we can conclude that after the implementation of the development vectors contemplated in the UAME's Implementation Plan and the support shown to the civilian population since 2016, change management is part of the organizational culture. However, we must point out that the UAME remains in an ongoing implementation phase, according to its project schedule, until the end of 2022.

In short, we found that seven of the eight steps of John Kotter's theory [8] were successfully achieved. Thus, leaving out the 5th step, "empowering employees". This situation is possibly due to the nature of the military institution, which has a solid hierarchy and centralizes the decisions of its Commander. In general, despite the criticisms of other authors, such as Galvin [73], on the application of the Kotter model in the Armed Forces, it was recognized that, in the scope of this research, the model is adequate to understand and describe the phenomenon and the creation of the EMS. Thus, it is quite evident that the Portuguese Army has been reducing the risk of disasters within the scope of the UN, to the extent that it has invested in a component (i.e., the UAME) that has allowed the reduction of disaster risk. The strengthening of this component allowed an effective response to the needs of civil authorities and, at the same time, deepening knowledge about disaster risk.

In the above paragraphs, we defined the conditions for successful change and answered the research question; however, the conditions for change were oriented towards internal concerns and issues of the formal organization. For a broader understanding of the phenomenon, this research goes further; to the extent that we will also address the relevant issues of relationship with society and other State entities. According to the data collected, the UAME is in close liaison with other military units of the Portuguese Army, Navy and Air Force through the COAME. In this context, support for the UAME can be 
provided on an unscheduled basis, essentially oriented towards supporting populations in unexpected emergency situations. In this situation, the UAME is normally used as an initial intervention force when the ANEPC cannot reach all locations. In addition, support can also be scheduled, i.e., when there are predictable periods of support, such as summer fires or winter floods in certain geographic areas. Scheduled support is identified in the PAMEXX, where it is explained what each Army unit must do in support of the ANEPC or another entity. As an example, the UAME maintains scheduled activities within the scope of the protocols established with the City Councils or with the Portuguese Institute for the Conservation of Nature and Forests (ICNF) regarding the surveillance of critical fire zones during the summer periods. In short, the UAME interacts with other entities mainly within the scope of previously established protocols or through unforeseen situations; acting, in the latter case, as an initial intervention force.

\section{Conclusions}

The main contribution of this research takes into account the UN International Strategy for Disaster Risk Reduction [2]. In this regard, we were able to conclude that Portugal actively participated in the strategy for defining disaster risk reduction through the ANEPC. In order to reinforce the Civil Protection System, the EMSR was created, which allowed the UAME to be prepared, in order to guarantee the country a better capacity (permanent, multifunctional, and comprehensive) that could respond to serious accidents or catastrophes [48]. The creation of the UAME is aligned with the UN strategy, as the conventional missions of the Portuguese Armed Forces were not initially prepared for crisis response actions. Furthermore, we found that there is still a way to go in terms of military actions in response to crises. Especially regarding Step 5 of the Kotter [9] model, as military institutions are very structured and, therefore, without much space to empower their collaborators.

This article also has some limitations, as it cannot be generalized. That is, the results obtained from the Portuguese military context may not be the same in other European countries; therefore, there is a need for further research. Another limitation is the difficulty of accessing military information, as military institutions are highly restricted organizations, resulting in a reduced number of interviews. However, the understanding we obtained from the different sources of data allowed for a relatively robust interpretation of the reality.

As for suggestions for future research, it may be relevant to conduct similar research in other European Union (EU) countries. The idea is to carry out in-depth scientific research between two or more EU member states, to understand which strategies organizations are using to be more efficient in their disaster response and risk reduction in light of the Kotter model [9]. As this article has several abbreviations, it was decided to add an Abbreviations that improves the readability of the article.

Author Contributions: Conceptualization, B.M. and J.R.; methodology, B.M. and J.R.; validation, J.R.; investigation, B.M.; resources, B.M. and J.R.; writing — original draft preparation, B.M.; writingreview and editing, B.M. and J.R.; project administration, B.M. and J.R.; funding acquisition, B.M. All authors have read and agreed to the published version of the manuscript.

Funding: This research received no external funding.

Institutional Review Board Statement: The study was conducted in accordance with the guidelines of the Declaration of Helsinki and approved under the scrutiny of the military organization where it took place.

Informed Consent Statement: Not applicable.

Data Availability Statement: The data used in this study was collected by the authors, any questions or clarifications can be addressed to the first author (p40500@ulusofona.pt).

Acknowledgments: The authors are thankful for the valuable support of the respondents.

Conflicts of Interest: The authors declare no conflict of interest. 


\begin{tabular}{ll} 
Abbreviations \\
Abbreviation & Meaning \\
ANEPC & National Civil Protection Emergency Authority \\
C2 & Command and Control \\
CAME & Course of Emergency Military Support \\
CFT & Portuguese Army's Land Forces Command \\
COAME & Emergency Military Support Operations Center \\
ECOSF & Elements of the Operational Component of the Forces System \\
EMS & Emergency Military Support \\
EMSR & Emergency Military Support Regiment \\
EU & European Union \\
FFAA & Armed Forces \\
GNR & National Republican Guard \\
ICNF & Institute for the Conservation of Nature and Forests \\
MSC & Military Strategic Concept \\
NPCP & National Preventive Civil Protection Strategy \\
PAMEEX & Portuguese Army Emergency Military Support Plan \\
PNEPC & National Civil Protection Emergency Plan \\
PNRRC & National Platform for Disaster Risk Reduction \\
SDG & Sustainable Development Goals \\
SIOPS & System of Protection and Relief Operations \\
TTP & Tactical Techniques and Procedures \\
UAME & Emergency Military Support Unit \\
UN & United Nations \\
UNDRR & United Nations Office for Disaster Reduction \\
UNISDR & International Strategy for Disaster Risk Reduction \\
& \\
\hline
\end{tabular}

\section{References}

1. National Platform for Disaster Risk Reduction. Available online: https://www.undrr.org/publication/guidelines-nationalplatforms-disaster-risk-reduction (accessed on 24 November 2021).

2. UN News. International Day for Disaster Risk Reduction, 13 October. Available online: https://www.un.org/en/observances/ disaster-reduction-day (accessed on 9 December 2021).

3. Leal Filho, W.; Azeiteiro, U.; Alves, F.; Pace, P.; Mifsud, M.; Brandli, L.; Caeiro, S.; Disterheft, A. Reinvigorating the sustainable development research agenda: The role of the sustainable development goals (SDG). Int. J. Sustain. Dev. World Ecol. 2018, 25, 131-142. [CrossRef]

4. Costa, J.; Cancela, D.; Reis, J. Neverland or tomorrowland? Addressing (In) compatibility among the SDG pillars in Europe. Int. J. Environ. Res. Public Health 2021, 18, 11858. [CrossRef] [PubMed]

5. UNDRR. Sendai Framework for Disaster Risk Reduction. Available online: https:/ /www.unisdr.org (accessed on 28 November 2021).

6. Estratégia Nacional para uma Proteção Civil Preventiva 2030. Available online: https://www.consultalex.gov.pt/ ConsultaPublica_Detail.aspx?Consulta_Id=188 (accessed on 14 December 2021).

7. Mills, A.; Durepos, G.; Wiebe, E. Encyclopedia of Case Study Research; SAGE Publications: Thousand Oaks, CA, USA, 2009.

8. Yin, R. Case Study Research and Applications: Design and Methods; SAGE Publications: Thousand Oaks, CA, USA, 2018.

9. Kotter, J. Leading change: Why transformation efforts fail. Harv. Bus. Rev. 2007, 86, 97-103.

10. Li, Y.; Taeihagh, A.; de Jong, M.; Klinke, A. Toward a commonly shared public policy perspective for analyzing risk coping strategies. Risk Anal. 2021, 41, 519-532. [CrossRef] [PubMed]

11. Haimes, Y. On the complex definition of risk: A systems-based approach. Risk Anal. Int. J. 2009, 29, 1647-1654. [CrossRef] [PubMed]

12. Andretta, M. Some considerations on the definition of risk based on concepts of systems theory and probability. Risk Anal. 2014, 34, 1184-1195. [CrossRef]

13. Zelentsov, V.; Ptushkin, A.; Zvyagin, V. New approach to the definition of risk. Int. J. Risk Assess. Manag. 2021, $24,73-83$. [CrossRef]

14. Ayyub, B.M. Systems resilience for multihazard environments: Definition, metrics, and valuation for decision making. Risk Anal 2014, 34, 340-355. [CrossRef]

15. Twigg, J. Disaster Risk Reduction; Overseas Development Institute: London, UK, 2015.

16. Paton, D.; Buergelt, P. Risk, transformation and adaptation: Ideas for reframing approaches to disaster risk reduction. Int. J. Environ. Res. Public Health 2019, 16, 2594. [CrossRef] 
17. Mearsheimer, J. A realist reply. Int. Secur. 1995, 20, 82-93. [CrossRef]

18. Nye, J.S., Jr. Power in the Global Information Age: From Realism to Globalization; Routledge: London, UK, 2004.

19. Drezner, D. Power and international relations: A temporal view. Eur. J. Int. Relat. 2021, 27, 29-52. [CrossRef]

20. Sørensen, G.; Møller, J.; Jackson, R. Introduction to International Relations: Theories and Approaches; Oxford University Press: Oxford, UK, 2021.

21. Savu, L. Realism, liberalism and constructivism in the pursuit of security. Strateg. XXI-Secur. Def. Fac. 2021, 17, 20-31. [CrossRef]

22. Viotti, P.; Kauppi, M. International Relations Theory; Rowman \& Littlefield: Lanham, MD, USA, 2019.

23. Kolodziej, E. Security and International Relations; Cambridge University Press: Cambridge, UK, 2005.

24. Pelling, M. The Vulnerability of Cities: Natural Disasters and Social Resilience; Routledge: London, UK, 2012.

25. Wijkman, A.; Timberlake, L. Natural Disasters: Acts of God or Acts of Man? Routledge: London, UK, 2021.

26. United Nations Office for Disaster Risk Reduction. Global Assessment Report on Disaster Risk Reduction. Available online: https:/ / www.undrr.org/publication/undrr-annual-report-2020 (accessed on 9 December 2021).

27. Rummukainen, M. Changes in climate and weather extremes in the 21st century. Wiley Interdiscip. Rev. Clim. Chang. 2012, 3, 115-129. [CrossRef]

28. Bell, J.; Brown, C.; Conlon, K.; Herring, S.; Kunkel, K.E.; Lawrimore, J.; Luber, G.; Schreck, C.; Smith Uejio, C.A. Changes in extreme events and the potential impacts on human health. J. Air Waste Manag. Assoc. 2018, 68, 265-287. [CrossRef] [PubMed]

29. ONU Pede Maior Cooperação Internacional para Combater Desastres Naturais. Available online: https://news.un.org/pt/story/ 2020/10/1729402 (accessed on 14 December 2021).

30. Resolution 44/236. International Decade for Natural Disaster Reduction. Available online: https://documents-dds-ny.un.org/ doc/RESOLUTION/GEN/NR0/549/95/IMG/NR054995.pdf?OpenElement (accessed on 11 January 2022).

31. Report of the World Conference on Natural Disaster Reduction, Yokohama, 23-27 May 1994. Available online: https://www. undrr.org/publication/report-world-conference-natural-disaster-reduction-yokohama-23-27-may-1994 (accessed on 7 January 2022).

32. Rodrigues, T. A estratégia internacional de redução de desastres. Territorium 2010, 17, 223-227. [CrossRef]

33. UN International Strategy for Disaster Reduction (UNISDR). Available online: https://sdgs.un.org/statements/un-internationalstrategy-disaster-reduction-unisdr-8377 (accessed on 28 December 2021).

34. United Nations. Resilience. Available online: https://www.undrr.org/terminology/resilience (accessed on 12 January 2022).

35. UNISDR. UNISDR Terminology on Disaster Risk Reduction. Available online: https://inee.org/system/files/resources/1-4_ UNISDR_Terminology_2009_copy.pdf. (accessed on 22 December 2021).

36. World Conference on Disaster Reduction. Hyogo Framework for Action 2005-2015. Available online: https://www.unisdr.org/ 2005/wcdr/intergover/official-doc/L-docs/Hyogo-framework-for-action-english.pdf (accessed on 18 December 2021).

37. Pozzer, C.; Cohen, S.; da Silva Costa, F. O Marco de Ação de Hyogo aplicado à gestão de risco de inundação no Brasil e em Portugal. Territorium 2014, 21, 49-70. [CrossRef]

38. Sendai Framework for Disaster Risk Reduction 2015-2030. Available online: https://www.preventionweb.net/files/43291_ sendaiframeworkfordrren.pdf (accessed on 22 December 2021).

39. Estratégia Nacional para uma Proteção Civil Preventiva 2030. Available online: https://dre.pt/dre/detalhe/resolucao-conselhoministros/112-2021-169418566 (accessed on 13 January 2022).

40. Paris Agreement for Climate Change. Available online: https://unfccc.int/process-and-meetings/the-paris-agreement/theparis-agreement (accessed on 6 January 2022)

41. The 17 Goals.The 2030 Agenda for Sustainable Development. Available online: https:/ /sdgs.un.org/goals (accessed on 7 January 2022).

42. Lei de Bases da Proteção Civil. Available online: https:/ / dre.pt/dre/detalhe/lei/27-2006-537862 (accessed on 9 January 2022).

43. Autoridade Nacional de Emergência e Proteção Civil. Available online: https://dre.pt/dre/legislacao-consolidada/decreto-lei/ 2019-121875485 (accessed on 5 January 2022).

44. Plataforma Nacional para a Redução do Risco de Catástrofes. Available online: https:/ / www.pnrrc.pt (accessed on 14 January 2022).

45. Plano Nacional de Emergência de Proteção Civil. Available online: http://www.prociv.pt/bk/RISCOSPREV/Documents/ Componentes_p\%C3\%BAblicas.pdf (accessed on 14 January 2022).

46. Sistema Integrado de Operações de Proteção e Socorro. Available online: http://www.prociv.pt/pt-pt/PROTECAOCIVIL/ SISTEMAPROTECAOCIVIL/SIOPS/Paginas/default.aspx (accessed on 14 January 2022).

47. Poderes e Competências. Available online: https://www.presidencia.pt/presidente-da-republica/as-funcoes/comandantesupremo-das-forcas-armadas/ (accessed on 9 January 2022).

48. Resolução do Conselho de Ministros n. 19/2013. Available online: https://dre.pt/dre/detalhe/resolucao-conselho-ministros/19 -2013-259967 (accessed on 2 December 2021).

49. Conceito Estratégico de Defesa Nacional. Available online: https://www.defesa.gov.pt/pt/comunicacao/documentos/Lists/ PDEFINTER_DocumentoLookupList/Conceito-Estrategico-de-Defesa-Nacional.pdf (accessed on 16 December 2021).

50. Chefe-Estado Maior do Exercito. Despacho n $n^{\circ}$ 44/CEME/2017 de 14 de Março. Conceito de Apoio Militar de Emergência; Army internal document; EME: Lisbon, Portugal, 2017. 
51. DL n. ${ }^{\circ}$ 113/2018, de 18 de Dezembro. Cria a Unidade de Emergência de Proteção e Socorro na Guarda Nacional Republicana. Available online: https:/ / www.pgdlisboa.pt/leis/lei_mostra_articulado.php?nid=2977\&tabela=leis\&ficha=1 (accessed on 29 January 2022).

52. Reis, J. Civil-military cooperation: Integrated logistics in response to the COVID-19 crisis. Logistics 2021, 5, 79. [CrossRef]

53. Palma, J. O Papel das Forças Armadas nas Operações Interagências de Combate às Ameaças. Cadernos Navais. Available online: https:/ / comum.rcaap.pt/bitstream/10400.26/12043/1/TII\%20_Novo_Palma\%20-\%20FFAA\%20Combate\%20Amea\% C3\%A7as\%20Emergente.pdf (accessed on 15 January 2022).

54. Gil, A. Intervenção do exército em situações de risco. Territorium 2017, 24, 235-247. [CrossRef]

55. Barroso, L. Os desafios operacionais do apoio militar de emergência. Revista Militar 2020, 6/7, 591-603.

56. Plano de Apoio Militar de Emergência do Exercito (PAMEEX). Available online: https://assets.exercito.pt/SiteAssets/GabCEME/ RCRPP/Documentos/Plano\%20de\%20Apoio\%20Militar\%20de\%20Emerg\%C3\%AAncia\%20do\%20Ex\%C3\%A9rcito.pdf (accessed on 15 January 2022).

57. Wood, T. Mudança Organizacional; Atlas: Rio de Janeiro, Brazil, 1995.

58. Simoes, P.; Esposito, M. Improving change management: How communication nature influences resistance to change. J. Manag. Dev. 2014, 33, 324-341. [CrossRef]

59. Lines, R. Influence of participation in strategic change: Resistance, organizational commitment and change goal achievement. J. Chang. Manag. 2004, 4, 193-215. [CrossRef]

60. Camara, P.; Guerra, P.; Rodrigues, J. Humanator XXI, Recurso Humanos e Sucesso Empresarial; Publicações Dom Quixote: Lisbon, Portugal, 2016.

61. Santos, L.; Lima, J. Orientações Metodológicas para a Elaboração de Trabalhos de Investigação; Cadernos do IUM, 8; Instituto de Estudos Superiores Militares: Lisbon, Portugal, 2019.

62. Reis, J.; Santo, P.; Melão, N. Impact of artificial intelligence research on politics of the European Union member states: The case study of Portugal. Sustainability 2020, 12, 6708. [CrossRef]

63. Reis, J.; Amorim, M.; Melão, N.; Cohen, Y.; Costa, J. Counterintelligence technologies: An exploratory case study of preliminary credibility assessment screening system in the Afghan National Defense and Security Forces. Information 2021, 12, 122. [CrossRef]

64. Given, L. The Sage Encyclopedia of Qualitative Research Methods; SAGE Publications: Thousand Oaks, CA, USA, 2008.

65. Thorpe, R.; Holt, R. The Sage Dictionary of Qualitative Management Research; SAGE Publications: Thousand Oaks, CA, USA, 2008.

66. Bloor, M.; Wood, F. Keywords in Qualitative Methods: A Vocabulary of Research Concepts; SAGE Publications: London, UK, 2006.

67. Mayring, P. Qualitative content analysis. A Companion Qual. Res. 2004, 1, 159-176.

68. Hsieh, H.; Shannon, S. Three approaches to qualitative content analysis. Qual. Health Res. 2005, 15, 1277-1288. [CrossRef]

69. Vaismoradi, M.; Turunen, H.; Bondas, T. Content analysis and thematic analysis: Implications for conducting a qualitative descriptive study. Nurs. Health Sci. 2013, 15, 398-405. [CrossRef]

70. Turco, M.; Jerez, S.; Augusto, S.; Tarín-Carrasco, P.; Ratola, N.; Jiménez-Guerrero, P.; Trigo, R. Climate drivers of the 2017 devastating fires in Portugal. Sci. Rep. 2019, 9, 1-8. [CrossRef]

71. Molina-Terrén, D.; Xanthopoulos, G.; Diakakis, M.; Ribeiro, L.; Caballero, D.; Delogu, G.; Viegas, D.; Silva, C.; Cardil, A. Analysis of forest fire fatalities in southern Europe: Spain, Portugal, Greece and Sardinia (Italy). Int. J. Wildland Fire 2019, 28 , 85-98. [CrossRef]

72. Augusto, S.; Ratola, N.; Tarín-Carrasco, P.; Jiménez-Guerrero, P.; Turco, M.; Schuhmacher, M.; Costa, S.; Teixeira, J.; Costa, C. Population exposure to particulate-matter and related mortality due to the Portuguese wildfires in October 2017 driven by storm Ophelia. Environ. Int. 2020, 144, 106056. [CrossRef]

73. Galvin, T.; Clark, L. Beyond Kotter's Leading Change. A Broad Perspective on Organizational Change for Senior US Military Leaders; Army War College Carlisle United States: Carlisle, PA, USA, 2015. 